\title{
РУСКА АЗБУКА ЈУЧЕ И ДАНАС ${ }^{1}$
}

Руска Федерација је вишенационална држава, на чијој територији живе данас представници 193 народа који говоре 300 језика и дијалеката. Језикословци наводе различити број језика - од 150 до 180, што је узроковано лингвистичким проблемом код одређивања статуса појединих језичких творевина - ,језик” или „дијалекат”. Општи мозаик националне припадности становника Русије показује да се у земљи могу наћи говорна лица већине светских језика. Али при креирању језичке стратегије из тог мултиетничког конгломерата најпре се издваја исконски, староседелачки живаљ, чија основна маса живи у Русији и нема своје државе у иностранству (Михальченко 2019: 8).

Представници појединих народа, почевши од предака, понекад столећима живе у Русији. Они јесу такође исконски становници. Али уколико имају своју државност у иностранству, не убрајају се у „староседелачке народе Русије” („коренные народы России”). У случају компактног, збијеног живљења они чине дијаспору. Развој њихових језика и култура зависи од њихове самоорганизације и самофинансирања, што је законодавно утврђено Федералним законом „О национално-културној аутономији” (16. 06. 1996).

Уређујући језички живот мултиетничке земље, држава има посебне обавезе према староседалачким народима, њиховим културама и језицима који немају друге државе у иностранству .

Коегзистенција (суживот) различитих језика у Руској Федерацији може се означити формулом ,јединство разноликости”, где јединство гарантује заједнички општедржавни језик, а шароликост се реализује функционисањем државних језика разних народа на нижим степеницама унутаретничке комуникације. У Русији је заједнички обједињавајући језик увек био руски језик - језик већинског дела становништва земље које према попису 2010. године чини 80,9\% популације (Михальченко 2019: 8). Усклађеност језичког живота РФ зависи од рационалне расподеле рада у јавној комуникацији из- 
међу два актора (две саставнице) - општедржавног језика и државних језика мањих етноса, који се користе у функцији уједињења, очувања и развоја њихових култура.

У таквој вишенационалној земљи као што је Руска Федерација није лако ускладити језички живот и језичко законодавство јер увек има одређене „напетости" између тежње да се сачува језичка разноликост и потребе за општим средством комуникације ради решавања државних и друштвених задатака (Вингендер 2019: 6). На први поглед, боље је заштићен језик већинског становништва, руски језик. Међутим у доба глобализације, отворености граница, тржишне економије и Интернета, ризику дестабилизације и деструктивним појавама изложени су у већој или мањој мери сви језици без изузетка. Испоставило се да је заштита потребна и најконзервативнијем језичком обележју - руској азбуци која се нашла у конкуренцији са латиничким писмом пре свега у рекламама и IT-технологијама. То није прво искушење у историји руске азбуке. Било је и раније тешких и драматичних тренутака, када је стајала на ивици пропасти. Занимљив и поучан је преглед свих превирања око ње.

Темељ руског писма чини једна од две најстарије славенске азбуке ћирилица. Током њеног прилагођавања вокалском систему руског језика и особито са развојем штампања књига више пута је искрсавала потреба за сређивањем азбуке и правописа.

Прву реформу руског писма иницирао је Петар I 1708-1710. Године 1708. Петар је наредио да се новим „грађанским” словима, која су била претходно направљена у Холандији и достављена у Русију уочи реформе, штампа „Геометрија” и друге грађанске књиге за припрему националног кадра. Године 1710. утврдио је образац нове азбуке. У њој су стара (црквена) писмена и нова (,грађанска”) слова приказана у поређењу (напоредо). Већ тада су елиминисана нека писмена црквене ћирилице ( $\xi$ - „кси”, $\psi$ - „пси”, $\omega$ - „омега” и др.). Истовремено у азбуку су уведена слова Э и Я, као и употреба великих и малих слова (у црквеној ћирилици била су у употреби само велика слова). Уведени су арапски бројеви који су у тој функцији заменили слова. Од тада све световне књиге и прве руске новине „Ведомости” штампају се руским словима. Повремено (спорадично) елиминисана писмена враћала су се у азбуку па онда на неко време опет нестајала. Поједина сувишна слова задржала су се у азбуци све до реформе 1917-1918. ( $\theta$ - „фита”, ь - ,jат”, I) (Иванова/Тимофеева 1997: 412).

Прелазак на нову графију, која се по облику разликовала од пређашњих писмена, подстакао је неке умове да се окрену латиничном писму. Странци, које је Петар довео из Европе, и месни „западњаци” сматрали су да нова графија, и поред реформисања, ипак заостаје за латиницом.

Препород православне духовности у доба владавине Јелисавете Петровне (1741-1761), млађе ћерке Петра I, праћен је покушајима истакнутих руских филолога, списатеља, научника - Ломоносова, Тредијаковског, Сумарокова - да заштите нову грађанску азбуку од помодарских, непромишљених 
иницијатива западњака. Крајем XVIII века њихови напади на „сувишна” слова, која немају аналога у латиничном писму, постају све оштрија.

У литератури о историји руског писма, посебно у последње време, има много алузија на активности слободних зидара у расправама о графији. На пример, један од руских масона, филозоф, мистик и преводилац А.Ф. Лабзин мрзео је дебели јер и потписивао своја писма „Безъеров”. Присталице руске азбуке пружили су отпор скраћивању словног састава грађанске азбуке. С тим у вези спомиње се једна епизода. Године 1832. А. Хумболт у Петербургу, будући гост А.Н. Олењина, изразио је мишљење о „потпуној сувишности дебелог јера" у руској азбуци. Њему је одговорио гроф А. А. Перовскиј (Антониј Погорелскиј). У посебном писму „У име слова Ђ” списатељ-фантаст и академик оповргнуо је гледиште немачког филозофа, потписавши одговор словом „Ь”. Писмо Перовског, са одушевљењем примљено у јавности, доживело је четири издања у руској штампи.

У јеку владавине Николаја I, када је 1833. године проглашен курс развоја државног живота у духу „Православља, самодржавља, народности”, три потпорна стуба руског конзерватизма, напади противника ћирилице јачају још више. С посебном оштрином одвија се борба умова у руској култури између присталица две струје - западњаштва и антизападњаштва (словенофилства). Расте број „филолошких” радова који намећу различите пројекте усавршавања руског писма - од замене појединих слова грађанске азбуке латиничним словима до потпуне замене азбуке латиничним писмом (К. М. Кодинскиј). Чак и опоненти таквог радикализма понекад су истицали контроверзне идеје. Тако, В. Г. Белински, који се веома критички осврнуо на иницијативу Кодинског, са̂м будући западњак, предлагао је да се слово „Й” замени за „Ј”.

Међутим, присталица исправљања или замене руског грађанског писма било је неупоредиво мање него противника таквих експеримената. Већина руских писаца и филолога XIX века без колебања је прихватила грађанско писмо које је увео Петар Први. Раскинути пупчану врпцу с матерњом ћирилицом у Русији више није било могуће.

Друга реформа у историји руског писма спроведена је 1917-1918. године. Припреме те реформе започете су у академијиним круговима (иницијаторима реформе) крајем 19. - почетком 20. века. Циљ је био као и код претходне реформе: дефинитивни раскид са сувишним словима, поједностављивање и унификација правописа. Године 1904. у окриљу АН створена је Правописна комисија на челу са Ф. Ф. Фортунатовим, која је исте године објавила „Прелиминарни извештај Правописне комисије” о нацрту новог правописа. Године 1912. Комисија је представила усавршену варијанту нацрта, али ни он није био прихваћен.

Године 1917. при АН је створена посебна припремна Правописна комисија, која је представила свој нацрт поједностављивања руског правописа. У заседању, чији председавајући је био А. А. Шахматов, учествовали су чланови претходне Правописне комисије 1904, научници, школски професори. Министарство просвете одобрило је закључке тог заседања и предложило да се реформисани правопис, а уз то и азбука, уведу у школе већ почетком нове 
школске године. Међутим, због Октобарске револуције 1917. године посао је био одложен. Нова власт је прихватила реформу која се ослањала на идеје разрађене још у Императорској академији наука 1904, 1912. и 1917. за време Николаја II, објавивши Декрете 23.12.1917. и 10.10.1918. о увођењу новог руског правописа у школску обуку. Правописна реформа подстакла је низ промена у азбучном саставу. Одлуком Народног комесаријата просвете на челу с А. В. Луначарским било је наложено: „искључити из употребе слово Ђ, доследно га замењивати словом Е; искључити из употребе $\boldsymbol{\theta}$ „фиту”, замењујући је словом $\Phi$; искључити слово $\mathbf{b}$ на крају речи и делова композита (сложеница); искључити слово I, замењујући га словом И".

Од 20-их до 30-их година XX века идеја латинизације руског писма поново је заживела пуном снагом. Према новинарским истраживањима (Жирнов 2010: 2-3) „процес је кренуо одозго” (уп.: Алпатов 2015: с. 12) мада без навођења извора.

И поред тога што је прихватила концепт друге правописне реформе, нова власт је сматрала да ипак није дорастао задацима нове револуционарне епохе, жудећи за много већим радикализмом графије. Земља је прелазила на нови календар, нови метарски систем, а писмо је остајало де факто старо, што се није уклапало у концепцију универзалне пролетерске културе и перспективе светске револуције која је по мишљењу идеолога Октобра 1917. била на помолу (Жирнов 2010: 56). Године 1919. Научно одељење Народног комесаријата просвете и лично нарком (народни комесар просвете) А. В. Луначарски предложили су прелазак писма свих народа Русије, укључујући и Русе, на латиницу. А. В. Луначарски је сматрао да би латинично писмо олакшало учење руског језика пролетерима свих земаља. Треба рећи да се не ради о неупућеним примитивцима. Идеолози пролетерске културе првог таласа били су велики интелектуалци, али су се залагали за идеалистичке идеје неопробане у пракси (у ствари западне проминијенције), искрено верујући да су спасоносне за народе бивше царске империје. Из тактичких разлога Лењин није журио с увођењем латиничне графије у руски језик, мада је идеју латинизације писма свих народа државе радника и сељака сматрао напредном (Жирнов 2010: 58). Има неких назнака у публикацијама да се прибојавао ужурбане, непромишљене активности у увођењу латиничног писма, која може нанети штету угледу нове власти и компромитовати саму идеју унификације свих графија на основу латинице (уп.: Алпатов 2015: 18).

Против ове идеје одлучно је иступило тада Друштво љубитеља руске словесности (Петросова 2007). Оно је формирало посебну комисију научника, филолога и професора која је објавила изјаву о негативним последицама (штетности) идеје латинизације руске азбуке ради „олакшања” учења руског језика. Процес увођења латиничног писма за Русе је био заустављен. Реформатори су своје активности окренули на друге народе мултиетничке државе. Нова власт није штедела новац, издвајајући огромна средства за стварање писама, речника, уџбеника и едукацију наставничког кадра за потребе многобројних етничких заједница. На латиницу је било преведено 50 од 72 језика Совјетског Савеза који су у време пројекта имали писмо. Књиге, периодична 
издања и службени документи штампали су се латиничним писмом. Процес латинизације је брзо напредовао. Камен спотицаја је остајао руски језик. Покретачи словне револуције нису га хтели оставити без промена. Осокољени постигнутим резултатима код других народа, реформатори су поново кренули на спровођење идеје о латинизацији руског писма. Године 1929. Народни комесаријат за просвету формирао је у ту сврху комисију за латинизацију руског језика на челу са угледним научником професором Н. Ф. Јаковљевим, уз учешће стручњака широког профила - добро припремљених лингвиста нове генерације, библиолога, инжењера полиграфије. Комисија је завршила са радом јануара 1930. године. Научници су донели своју резолуцију о неизбежности преласка Руса на јединствени интернационални алфабет на латиничној основи због политичких и економских прилика. Идеју латинизације и концепцију Јаковљева са одушевљењем је дочекао А. В. Луначарски (у то време већ виценарком просвете), објавивши истовремено у лењинградским новинама два чланка заредом са политичким образложењем идеје о латинизацији руског писма.

Ново руководство Наркомпроса предало је резултате рада комисије на разматрање и утврђење Политбироу ЦК партије. На заседању 1. марта 1930. године под председништвом И. В. Стаљина била је донета одлука о којој се дуго ништа није знало. Била је обелодањена први пут тек у 17. додатном тому Стаљинових сабраних дела. Одлуком Политбироа било је наложено сместа обуставити сваку активност у погледу реализације пројекта и латинизација руског језика. После тога више се није могло расправљати о пројекту Н. Ф. Јаковљева у јавности. О њему се ћутало више деценија (Алпатов 2015: 20). Од средине 1930. године почиње нови заокрет у језичкој политици државе. Покренут је процес масовног превођења новонасталих латиничних писама многобројних народа земље у ћириличко писмо. Процес се опет брзо и успешно одвијао.

Нови потреси затекли су руску азбуку у последњој деценији XX века: распад земље, проглашење самосталности Руске Федерације, смена државног уређења и курса развоја, глобализација, маркетингизација друштва, интернетизација, отварање граница, демократизација друштва и културе, хаос и поступан излазак из њега.

Нестала је језичка цензура, почело је доба језичке слободе и разноврсног језичког експериментисања које је најпре погодило азбучно писмо (у комерцијалне сврхе). Аутори постсовјетске рекламе су црпили своје идеје углавном из два континуума - из предреволуционарног правописа царског периода на почетку XX века и енглеског језика (ретко из других западних језика). Квалитет рекламе зависио је од стручности (професионализма) и укуса рекламодаваца. И поред успелих, духовитих и укусних остварења, у реклами тих година било је много шунда и кича, о чему сведочи занимљива грађа у радовима о реклами из овог периода (В. Г. Костомаров, И. П. Прядко, И. В. Высоцкаја идр.).

У спољашњој реклами, тј. на фирмама, ушло је у моду преношење архаичних слова из старог предреволуционарног правописа - дебелог јера на 
крају речи Ђ, јата Ђ, понекад и слова I, нпр.: „Самоваръ” (продавница), „Яръ” (кафана), „Аристократь” (ресторан); „Трактиръ” (фирма на Јарославској железничкој станици), „Пушкинь” (кафана), „Дачникъ” (продавница), „Модернъ” (позориште), „Грандъ-Имперіаль” (ресторан). У граду Сергијев Посад под фирмом ресторана „Русский дворик” запажен је текст са курзивним јатом „Чай, объды, ужиньл" (Прядко 2006: 91).

Многи произвођачи прехрамбених производа почели су писати дебело јер на крају својих имена, нпр.: Облепиха протертая с сахаром СТОЕВЪ; хрен МАХЕЕВЪ; Сгущенное молоко РОГАЧЕВЪ.

Стара слова појављују се у називима комерцијалних предузећа, новина и часописа: „Адресъ” (агенција за некретнине), „Кварталь” (агенција за некретнине), „Практикумъ” (агенција за некретнине), „Русский міръ” (издавачко предузеће), „Правопорядокъ” (дневни лист), наслов чланка „Будь готовъ!” (часопис „Домовой”), „Распутинъ” (часопис), логотипима појединих издања „На дны”, „Россія”, „Коммерсантъ”. Тако се дебели јер, логотип часописа „Коммерсантъ”, употребљава често уместо пуног назива, нпр.:

“'Ђ” выяснил у крупных банков, насколько активно граждане подтверждают право на каникуль; Об итогах голосования - в материале "Ђ"; Глава ЕАБР в интервью "Һ" рассказывает о том, что делает банк для развития и интеграции своих стран; За время, прошедшее с момента выхода предылущего номера „ъ-Науки”, не осталось сомнения, что пандемия, вызванная коронавирусом стала главным эпидемическим событием XXI века; „Коммерсанть Стиль” решил разобраться в стилях ювелирного искусства.

Архаична слова из правописа предреволуционарног раздобља јесу одређени оријентири који упућују потрошаче или читаоце периодичних издања на одређени историјски контекст. Захваљујући „угледу старине” декларише се солидност, озбиљност, поузданост бренда, а према томе и привлачност производа, дела или посла који се нуди (Прядко 2006: 93). По нашем мишљењу, то је донекле декларисање и идејне оријентације наручилаца рекламе.

Други извор модерног „,азбукропотреса” су компјутеризација и мобилна телефонија које су подстакле ширење енглеског дискурса (посебно код омладине) и латиничног писма у виртуелном простору, на интернету и смс порукама. Врло брзо „коктејл” латинице и азбучног писма отпочео је свој живот у фирмама на улазним вратима комерцијалних објеката и у рекламним текстовима широм земље. Довитљивост и фантазија аутора реклама у стварању језичког шунда ради привлачења муштерија и потрошача су безграничне (Высоцкая 2010: 471-474). Латинични уметак може да чини слово, део речи, део текста. Латинично слово може бити уметнуто у разне делове речи. Најбоље се види у позицији почетка речи, нпр.: Э. Лу. НАИBNO. SУПEP (позоришни плакат); Nептун (школа подводног пливања); $Z$ EБРА (продавница);

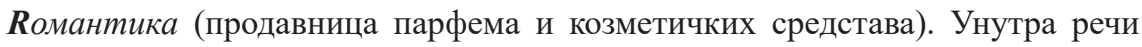
латинично слово види се слабије па се често даје у другој боји: Заверкалье (салон лепоте); ДИВИZИОН (дигиталне технологије); Деfиле (Италијанска обућа). 
Одређени стилистички ефекат даје удвајање сугласника. Често се користи у неформалној интернет-комуникацији: Соленьй арбуZz 'Слана лубеницุa '(бар); ПАРАДОGS (назив позоришта); у руским презименима на-ов: Тюльnaноff (продавница цвећа), Насосоff (сеоска продавница црпка и шмркова), Блиноff (мрежа кафана). У наведеним примерима латинично слово само замењује руско слово, али не и његов изговор. Речи с латиничним уметком и без њега читају се исто, на руски начин: „Бикіни” и „Бикини”, „Онегін” (ресторан) и „Онегин” (књижевни лик). Изузетак је реч Іболит (мрежа апотека и име омиљеног лика дечје књижевности), где слово I чита се на енглески начин као (ai) и замењује исти звуковни спој „ай” у руском изразу: „Ай, болит!” и имену лика дечје бајке К. Чуковског „Доктор Айболит” (Доктор Јојболи). Уз латинична слова у интернет комуникацији користе се и технички симболи. Тако, руско слово „а” замењује се знаком електронске поште @: Д@РИМ подключение, Д@РОМ развлечения; Ст@рт ТЕЛЕКОМ.

Још један помодарски тренд савремене рекламе је „графички каламбур" - хибридизација речи спојем (спајањем) фреквентне енглеске или друге стране речи и једног дела руске речи у једну целину: SIMEЙНЫЕ ИСТОРИИ

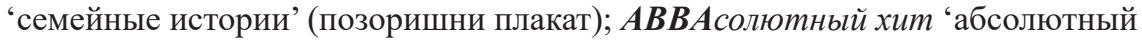
хит’; Двигай на вечеGREEN火y! 'Двигай на вечеринку!' (TV реклама пива Tuborg-Green); ОТTOхни от магазинов! 'отдохни от магазинов!' (каталог ОТТО); Вееглога 'берлога' (назив пивцнице).

Веома много графичких каламбура направљено је на основу енглеске скраћенице О.К. која се употребљава уместо руског суфикса -ок (често са деминутивним и хипокористичним значењем): ГлазОК 'око О.К.' (продавница оптике); КлубОК 'Клуб О.К.' (шоу-кафана); АрбузОК ‘Лубеница О.К.' (продавница воћа и поврћа); Мастер ОК! (фирма продавнице); Блин. ок! 'Палачинка. О.К.!' (Мрежа палачинкарница).

У фирмама данашњих продавница, посебно у провинцији, користе се често елементи адресе електронске поште уз азбучни текст основног назива: Куда.ru (туристичка агенција); Телефон.rи (сервис мобилних телефона); Адреналин.ги (продавница спортске опреме и одеће).

Помодарски елемент данашње рекламе постала је учестала употреба у руским фирмама симбола $\&$, који замењује енглески везник and: 2 МОДА \& КОМФОРТ; РОЗЕТКИ $\boldsymbol{\&}$ ВЫКЛЮЧАТЕЛИ; ЧАЙ $\&$ КОФЕ; ДВЕРИ $\boldsymbol{\&}$ ОКНА; МАТРАСЫ \& КРОВАТИ; БАР \& ГРИЛЬ; Мастер \& Маргарита (фото студија); ВИНТИК $\&$ ШПУНТИК; ПЕС \& КОТ. Ради већег учинка овом симболу може се додати „без везе” још један семиотички елемент, из посве другог континуума $\left(\boldsymbol{\&} \boldsymbol{K}^{\boldsymbol{\theta}}\right)$, напр.: банька ЖАР $\boldsymbol{\&} \boldsymbol{K}^{\boldsymbol{o}} ;$ ПИВ $\boldsymbol{\&} \boldsymbol{K}^{\boldsymbol{o}}$.

У реклами прехрамбених производа такође се срећу елементи енглеског језика и латинице: the КАША (овсене пахуљице, производ из насеља Бољшевик, Московске области); Водка organic KREMLIN Award Vintage.

\footnotetext{
${ }^{2}$ Иста тендеција запажена је и у Београду, уп.: Хлеб $\boldsymbol{\&}$ кифле (фирма популарне пекаре у Кнез Михаиловој).
} 
Дубокипотресизахватили сучитав језички систем, несамоазбучнописмо. Језичка култура је све више опадала у свим сферама јавне комуникације, што је алармирало друштво ${ }^{3}$ и подстицало захтеве за увођењем мера превенције, заштите руског језика и кажњавањем непримереног језичког понашања и аналфабетизма у јавном простору. Постсовјетска законодавна наука се није оглушила о ту поруку. Законодавство се усмерило на заштиту руског и других језика вишенационалне државе. Почела је активно да се развија нова грана руске правне науке - језичко законодавство.

Царска Русија није имала ни посебан закон о руском језику, а камоли о употреби месних говора. Али године 1906. „Зборник закона Руске царевине” први пут забележио је правни статус руског језика. У одељку „Основни државни закони” руски језик почео је да се дефинише као општедржавни и обавезни у војсци, морнарици и у свим државним и јавним установама земље.

У Совјетском Савезу такође није било законских аката о регулисању језичке употребе у вишенационалној држави. Тек године 1990. био је усвојен Закон „О језицима народа СССР-а”. Према њему руски језик у тим приликама добио је статус службеног (званичног), али не и државног (!) језика. Међутим, тај закон није важио дуго, нешто више од годину дана, до јесени 1991. године, па је његов утицај био временски ограничен и није био делотворан.

Крајем те исте године (25. 10. 1991) већ у новој Русији био је усвојен Закон РСФСР „О језицима народа Руске Федерације”, који је отишао корак даље, прогласивши руски језик за државни.

Следећи корак било је доношење Федералног закона „О државном језику Руске Федерације” 2005. године, чиме је потврђен статус руског језика као државног, одређене сфере обавезне употребе, гарантована заштита и подршка у разним областима (медијима, средствима комуникације, реклами, декорисању фирми разних објеката, излога, у документима) од негативних појава: безразложне употребе туђица, иностраних термина и израза, вулгаризама, псовки, шатровачких речи и израза, погрешног нагласка; зајамчена права грађана на коришћење руског језика (у образовању, приликом добијања информације у органима државне власти свих нивоа, у медијима), гарантована помоћ и подршка у припреми стручног кадра за наставу и научно истраживање руског језика, помоћ у издању нормативних приручника, речника и граматика руског језика; прописана одговорност за кршење Закона.

У поједине чланове Закона двапут су уношене измене и допуне, озакоњене посебним нормативним актима из 2013. и 2014. године. У њима је шире прописана сфера употребе државног руског језика, нпр. у припреми и провођењу избора и референдума, судском поступку (у уставном, цивилном и кривичном праву), у званичном објављивању текста међународних уговора Руске Федерације и других правних аката, у исправама, у јавном извођењу

\footnotetext{
${ }^{3}$ Довољно је погледати наслове научних и новинарских радова из тог раздобља: „Ублюдок, гнида, пустозвон! ... тут отключили микрофон” // О некоторых лексических особенностях дискуссий российских политиков (Устюжанин 1999); „Русский язык на грани нервного срыва” (Кронгауз 2007); „Экспансия латиницы в русскоязычных текстах как нарушение языковой экологии" (Вакулова 2008) итд.
} 
књижевних и уметничких дела, у образовним програмима, културно-просветним и забавним приредбама, у пројекцији филмова, у реклами. У свим тим подручјима, а такође и у реклами, у законом предвиђеним приликама уз руски језик могу се употребљавати државни језици република које улазе у састав Русије, као и други језици њених народа, а у одређеним приликама страни језици.

Пооштрене су рестриктивне мере због кршења законодавства о руском језику као државном. Забрањује се и ограничава филмска продукција која садржи непристојне изразе (таква лексика не сме бити у филму који се третира као национални). Закон забрањује издавање дозволе таквим филмовима. Промет филмова без дозволе кажњава се. Уведена је административна одговорност за поновно кршење закона.

Закон о државном језику је дао подстрек даљем развоју законодавства о руском језику. Данас је донето преко стотину законодавних аката о руском језику као државном језику Руске Федерације. Његов статус је гарантован Уставом земље из 1993. године и новом редакцијом Устава из 2020. године: „Државни језик Руске Федерације на читавој њеној територији је руски језик (уз додатак) као језик државотворног народа који улази у вишенащионални савез равноправних народа" (Конституция РФ 2020, чл. 68, т. 1). Полазећи од начела једнакости и самоодређења, Устав РФ пружио је републикама право на успостављање својих државних језика (Конституция РФ 2020, чл. 68, т. 2). У Закону из 2005. године прописано је да се обавеза употребе државног језика Руске Федерације не сме третирати као негирање или ускраћивање права државних језика других република које су у саставу Руске Федерације, као и језика народа РФ.

Језичка ситуација у Русији је доста сложена јер се у земљи употребљавају језици различитог порекла (индоевропски, севернокавкаски, турски, монголски, угрофински, тунгуско-манџурски, палеоазијски и самодијски), уз то говорници тих језика размештени су у различитим крајевима (рејонима) земље са разним степеном компактности. Према административној подели територије, Русија има 85 субјеката са различитим статусом. Плуралистистички прилаз језичкој разноврсности Руске Федерације изражен је у варијетету типова друштвене комуникације у разним субјектима у складу са њиховом спецификом. У зависности од националног састава они имају једнокомпонентни, двокомпонентни, трокомпонентни, вишекомпонентни и диференцирани тип друштвене комуникације (Михальченко 2019: 10).

У субјектима (областима) Руске Федерације, где Руси чине 80-95 одсто популације, функционише једнокомпонентан модел социјално-комуникативног система (СКС): употребљава се руски језик у књижевном, разговорном или дијалекатском облику. Конвергенција са читавом земљом реализује се преко државног књижевног руског језика, док се јединство унутар руске језичке заједнице обезбеђује уз помоћ књижевног језика и других облика разговорног језика и дијалеката.

Већина република (22) које улазе у састав Руске Федерације имају двокомпонентан модел СКС: руски језик као државни језик Руске Федерације и 
републички државни језик (превладавајућег етноса). У неким републикама (Мордовија, Мариј Ел, Коми, Кабардино-Балкарија) постоји „отежан” (сложенији) двокомпонентан модел СКС: руски језик као државни језик Руске Федерације и две варијанте истог књижевног језика или два књижевна језика који су добили статус државног језика. Република Крим има трокомпонентан модел СКС: руски језик као државни језик Руске Федерације и три државна језика: руски, украјински и кримско-татарски језик. Дагестан и Карачајево-Черкесија имају вишекомпонентан модел СКС: руски језик као државни језик Руске Федерације и друге писмене језике које имају статус државних језика ових Република.

Године 2014. Указом Председника РФ В. В. Путина формиран је Савет за руски језик при Председнику Руске Федерације „у циљу обезбеђења развоја, заштите и подршке руског језика као државног језика Руске Федерације, као и повећања ефикасности активности државних органа Руске Федерације у тој области". За председника Већа именован је праунук Лава Толстоја В. И. Толстој. У функције Савета спада решавање важних задатака око пружања подршке руском језику у Русији и иностранству. У раду Савета учествују руководиоци водећих лингвистичких институција, угледни научници, културни и просветни радници, професори, библиолози, редактори часописа, издавачи. Заседања су добро припремљена, транспарентна, проводе се редовно, уживо, уз отворене расправе. Као правило имају напет и разноврстан дневни ред и много излагача из разних крајева Русије.

Међу темама последње седнице Савета новембра 2019. године (Совет РЯ 2019), којом је председавао В. Путин, било је усклађивање односа између руског језика као државног и националних језика других народа. У рефератима и расправама наглашавало се да за грађане Русије руски језик не може бити нематерњи, страни. Двојезична средина у којој расту деца у националним регионима Русије благо је и поклон судбине, а не казна и неприлика. Човек који зна говорити и мислити на два матерња језика, а још боље на три и више, увек има предности. Ово преимућство мора да се реализује у раду, животу и стваралаштву. Стварање услова за реализацију овог преимућства је један од главних задатака језичке политике Русије. На државном нивоу треба пропагирати идеју о предности вишејезичности у односу на једнојезичност, о потреби свеопштег владања руским језиком, не уместо етничког језика него уз њега.

Још једна тема око које се у расправама ломе копља јесте појам језичке норме јер према Закону о државном језику норму треба стриктно, неизоставно поштовати. С тим у вези поставља се питање из којих извора треба црпети информације о правилности јер у њима често нема јединства. То питање највише мучи правнике који желе имати при руци нове квалитетне, унификоване језичке приручнике. Посебно им недостаје модерни једнојезички речник руског језика који је „на помолу” од 2009. године. Поуздани нормативни извори од великог су значаја и у деловодству различитих државних министарстава и ресора који се свакодневно баве „папирологијом”, припремом свакојаке документације. По устаљеној традицији академске лингвистичке институције, најпре Институт за руски језик Виноградов РАН у Москви и 
Институт лингвистичких истраживања РАН у Санкт Петербургу, као и катедре водећих универзитета земље, прате норму савременог руског језика, врше анализу њених варијаната, избор и фиксацију у речницима, приручницима и граматикама. Али обнављање речника и приручника ради стварања нормативне базе државног језика иде доста споро. На споменутом заседању Савета за руски језик (2019) подржан је рад на стварању амбициозног пројекта јединствене дигиталне државне платформе „Национални речнички фонд”, за који се планира да ће завршити до 2022. године.

Закон о државном језику је дао подстрек даљем развоју језичког законодавства. Данас је донето преко стотину законодавних аката о руском језику као државном језику Руске Федерације.

Језичко питање је приоритетно у државној политици Русије јер је део борбе за државну безбедност и мир многонационалне земље. Њено језичко законодавство стално се развија, допуњује и усавршава. Солидно је разрађено, модерно и свеобухватно, мада је посла још врло много. Налази се одмах иза француског језичког законодавства, најстаријег у свету. Стручњаци сматрају да у целини одговара међународним стандардима.

Широке расправе у јавности о језичким питањима, критика језика појединих законских дефиниција због магловитости или недоумица у тумачењу доприносе усавршавању руског језичког законодавства: истина се рађа у спору. Основни закони о руском језику постају тема научних расправа, магистарских и докторских теза, новинарских чланака и школских састава. Међутим, примећује се да се руско језичко законодавство не фокусира посебно на писмо. Оно је имплицитно заштићено у свим актима језичког законодавства. Мирнијим тоном се анализира данас чак и безумни пројект јадног Н. Ф. Јаковљева, који није био под репресијом, али је остао без посла (Алпатов 2015). У радовима последњих година, углавном млађих аутора, срећу се и опрезне позитивне оцене језичке игре у јавном простору са елементима разних писама и језика у сврху „пецања потрошача”. У колективној свести, изгледа, усталило се мишљење да руско писмо више није угрожено. Историјски избор је учињен једном заувек и ревизија није могућа.

\section{ЛИТЕРАТУРА}

Алпатов 2015: Алпатов В.М. Русская латиница Н.Ф. Яковлева / В.М. Алпатов // Научный диалог: - 2015. - № 3 (39). - С. 8-28.

Высоцкая 2010: И.В. Высоцкая И.В. „Свое” и „Чужое”, или взаимодействие кириллицы и латиниць в современном рекламном тексте / И.В. Высоцкая // Вестник нижегородского университета им. Н.И. Лобачевского. - 2010. - № 4 (2). - С. 471-474.

Жирнов 2010: Жирнов Е. О латинизации русского алфавита / Е. Жирнов // Коммерсанть Власть: - 2010. - № 2 (856). - С. 56-61.

Вингендер 2019: Вингендер М. Разнообразие и единство: языковые идеологии в Советском Союзе и Российской Федерации / М. Вингендер // Пер- 
спективы и вызовы языковой политики и языковой ситуации в Крыму. Международный круглый стол (5-6 ноября 2019, Москва). - 2019. - С. $6-7$.

Иванова/Тимофеева 1997: Иванова В.Ф., Тимофеева Г.Г. Реформы азбуки и правописания / Русский язык. Энциклопедия. // Гл. ред. Ю.Н. Караулов. - 2-е изд., перераб. и доп. - М.: Большая Российская энциклопедия; Дрофа, 1997. - 412-413.

Михальченко 2010: Михальченко В.Ю. Динамика языковой ситуации в Российской Федерации / В.Ю.Михальченко // Перспективы и вызовы языковой политики и языковой ситуации в Крыму. Международный круглый стол (5-6 ноября 2019, Москва). - 2019. - С. 8-24.

Петросова 2007: (чланак доступан on-line) Петросова А. Как была спасена кириллица. Из истории попыток латинизации русского алфавита / A. Петросова // Столетие: 2007. http://www.stoletie.ru/obschestvo/kak_bila spasena_kirillica.htm 06.07.2020.

Прядко 2006: Прядко И.П. Дореформенная орфография и современная реклама / И.П. Прядко // La Revue Russe: - 2006. - № 28. - pp. 91-94.

Совет РЯ 2019: (стенограм доступан on-line) Заседание Совета по русскому языку 05.11.2019. http://kremlin.ru/events/president/news/61986 06.07.2020.

Конституция РФ 2020: (стенограм доступан on-line) Конституция Российской Федерации http://publication.pravo.gov.ru/Document/ View/0001202007040001 06.07.2020.

Галина Георгиевна Тяпко

РУССКАЯ АЗБУКА ВЧЕРА И СЕГОДНЯ

Резюме

Статья посвящена анализу перипетий русской азбуки в разные исторические эпохи, проливающие свет на ее функционирование в современном публичном пространстве.

Начало динамическим процессам в азбуке положила реформа Петра I, в результате которой архаичное кириллическое (церковное) письмо было заменено гражданским шрифтом, освобожденным от „лишних” букв, хотя их употребление отмечается вплоть до второй реформы азбуки (1917-1918). Отдельные инициативы по латинизации русского письма в досоветский период не нашли поддержки в обществе.

В XX в. русская азбука оказалась на перепутье. Вторая реформа, начатая императорской АН (1904), и принятая с третьей попытки уже после Октябрьской революции (1918), казалась недостаточной идеологам нового строя, намеревавшимся унифицировать письменность всех народов многонационального государства, на основе латинского алфавита, включая и русский язык. Концепция латинизации русского языка, тщательно подготовленная видным лингвистом Н.Ф. Яковлевым и его командой, была неожиданно отвергнута волевым решением И.В.Сталина на заседании Политбюро ВКПб, спасшим русскую азбуку от гибели. Более того, начался обратный процесс - переход всех языков на кириллицу, включая языки, подвергшиеся латинизации в 20-30-е гг. Эти парадоксальные события косвенным образом укрепили позиции азбучного письма в России. 
На конкретном материале в статье анализируются образцы азбучных модификаций в постсоветский период, отмечаемые в рекламной продукции: использование символов „кириллической старины” и элементов английского языка. На этом историческом фоне выявляется некоторое сходство динамических процессов в русской азбуке до- и постсоветского периодов: включение архаичных букв кириллической графики или элементов латинского письма в состав русского слова или фразы. Анализируются защитные механизмы языкового законодательства, направленные на совершенствование русского языка как государственного и его гармоничное взаимодействие с государственными языками других народов многонациональной России.

Ключевые слова: реформы русской азбуки, латиница, публичное пространство, государственный язык, русское языковое законодательство 